ZalǫcZnilf

DOI 10.21697/zk.2020.7.05

\title{
(AUTO)REFLEKSYJNOŚĆ W TREMIE ALFREDA HITCHCOCKA. O ADAPTACJI POWIEŚCI SELWYNA JEPSONA
}

ROBERT BIRKHOLC

Wydział Polonistyki UW

Faculty of Polish Studies, University of Warsaw beerek38@wp.pl

ORCID: 0000-0002-5192-4997

Twórczość Alfreda Hitchcocka nie daje się łatwo wpisać w historycznofilmowe periodyzacje i typologiczne podziały. Filmy „mistrza suspensu”, od 1939 roku realizowane w ramach hollywoodzkiego systemu produkcyjnego, bywają niekiedy zaliczane do paradygmatu narracji klasycznej ${ }^{1}$, której wyznacznikami są m.in.: koncentracja na fabule, przezroczystość formalna i nakierowanie na emocje widza ${ }^{2}$. Można uznać, że powyższa charakterystyka jest redukcyjna dla dużej części filmów „złotej ery Hollywood”, jednak dzieła Hitchcocka w sposób szczególnie silny naruszają normy tak

${ }^{1}$ Jacek Ostaszewski omawia niektóre cechy charakterystyczne narracji klasycznej na przykładzie filmu Północ, północny zachód (North by Northwest, 1959). Co znamienne, Ostaszewski wspomina jednak o Hitchcocku także w rozdziale poświęconym narracji modernistycznej, uznając, że kino noir zapowiadało modernizm filmowy. J. Ostaszewski, Historia narracji filmowej, Kraków [cop. 2018], s. 111-112, 148.

2 Na temat wyznaczników kina klasycznego zob. m.in. M. Przylipiak, Kino stylu zerowego. Dwadzieścia lat później, Sopot 2016.

3 Jak pisze Rafał Syska, kino klasyczne „[...] na pozór oparte było na stabilnych wzorcach fabularnych, miało unikać odważnych eksperymentów narracyjnych, preferować konserwatywną ideologię, a także rozrywkę i eskapizm. Jak bardzo ten pogląd jest niesprawiedliwy, wie niemal każdy kinoman”. Zob. R. Syska, Wstęp, [w:] Kino klasyczne, red. T. Lubelski, I. Sowińska, R. Syska, Kraków [cop. 2011], s. 15. 
definiowanego kina klasycznego ${ }^{4}$. Hołubiony przez francuskich nowofalowców autorski styl reżysera, silna subiektywizacja narracji, zainteresowanie podmiotami rozszczepionymi wewnętrznie czy wreszcie zabiegi wytrącające odbiorcę z pozycji biernego widza, nasuwają skojarzenia z zupełnie przeciwstawnym paradygmatem narracji modernistycznej. ${ }^{5}$. Jedną z najważniejszych cech modernizmu jest autorefleksyjność, która w kinie Hitchcocka objawia się chociażby w Oknie na podwórze (Rear Window, 1954), obrazie tematyzującym rolę widza filmowego.

Z drugiej strony, dzieła brytyjsko-amerykańskiego twórcy - mawiającego, że film to życie, z którego wymazano plamy nudy - sytuują się jednak na antypodach twórczości takich modernistów jak Michelangelo Antonioni czy Jean-Luc Godard. Hitchcock nie rezygnuje z klasycznych schematów fabularnych, nie oddramatyzowuje akcji i nie posługuje się trudną w odbiorze, eksperymentalną formą audiowizualną ${ }^{6}$. Warto scharakteryzować

4 Zob. „Pisząc o odstępstwach, nie sposób nie wspomnieć o Alfredzie Hitchcocku. Reżyser ten zajmował niezwykłą pozycję wśród twórców hollywoodzkich. Robił filmy doskonale mieszczące się w ówczesnych standardach, dobrze odbierane przez publiczność, a dzięki temu szanowane przez producentów. Wyostrzona świadomość formy filmowej sprawiała jednak, że Hitchcock ciągle eksperymentował. Był niewątpliwie największym eksperymentatorem Hollywoodu. Wiele z jego rozwiązań zdawało się wykraczać poza to, co amerykańskie wytwórnie filmowe byłyby skłonne zaakceptować [...], jednak temu reżyserowi zawsze udawało się zachować równowagę między śmiałością formy a jej zrozumiałością dla przeciętnego widza"; M. Przylipiak, op. cit., s. 116.

5 Związki Hitchcocka z kinem modernistycznym w dalszym ciągu nie zostały wyczerpująco opisane, zagadnienie było jednak kilkakrotnie poruszane. Zob. m.in.: A.B. Kovács, Screening Modernism. European Art Cinema, 1950-1980 (Cinema and Modernity), Chicago - London 2007, s. 248-251; T. Hemmeter, Hitchcock's Narrative Modernism: Ironies of Fictional Time, [w:] A Companion to Hitchcock, eds. T. Leitch, L. Poague, Malden (MA) - Oxford, s. 67-85.

6 Jacek Ostaszewski wymienia następujące cechy „narracji modernistycznej”, które odróżniają ją od „narracji klasycznej”: trudna w odbiorze forma, otwarte zakończenie, koncentracja na konflikcie wewnętrznym bohatera, motyw alienacji, oddramatyzowanie akcji, akcentowanie roli przypadku oraz subiektywizacja. Por. J. Ostaszewski, Nowe kino, nowa narracja, [w:] Kino epoki nowofalowej, red. T. Lubelski, I. Sowińska, R. Syska, Kraków 2016, s. 31-61. 
zabiegi autorefleksyjne twórcy, które dokonywane są w ramach pozornie klasycznych opowieści i znacznie różnią się od samozwrotnych chwytów stosowanych przez reżyserów europejskiego kina artystycznego. Dobrym materiałem badawczym jest pod tym względem kryminał z elementami komediowymi, czyli Trema (Stage Fright, 1950). Analiza filmu może rzucić nowe światło nie tylko na samo dzieło, niesłusznie spychane na margines twórczości Hitchcocka ${ }^{7}$, lecz także na zagadnienie metafikcjonalności w kinie reżysera. Dodatkowym kontekstem badań warto uczynić pierwowzór literacki Tremy - mało znaną powieść Uciekający człowiek (Man Running) Selwyna Jepsona - gdyż zestawienie utworu literackiego $\mathrm{z}$ adaptacją pomoże w rozpoznaniu strategii twórczych reżysera. Dzięki głębszemu osadzeniu akcji w środowisku teatralnym, wprowadzeniu wieloznacznego symbolu kurtyny, metalepsie autorskiej, problematyzacji kwestii tożsamości bohaterów oraz „kłamstwu” narracyjnemu Hitchcock znacznie rozszerzył zakres znaczeniowy oryginału.

Parafrazując literaturoznawczą definicję Wojciecha Browarnego, można przyjąć, że refleksyjność ${ }^{8}$ to autoreprezentacja filmu jako medium procesu poznania, zrealizowana filmowymi metodami, na przykład przez powtórzenie motywu, zwielokrotnienie narratora czy system zróżnicowanych punktów widzenia 9 . Autorefleksyjność natomiast to „tendencja ideowa

${ }^{7}$ Choć w niezwykle obszernej anglojęzycznej bibliografii Hitchcocka zdarzały się teksty poświęcone Tremie, to jednak film ten pozostaje jednym z najrzadziej analizowanych dzieł reżysera zrealizowanych po 1939 roku. Na temat Tremy zob. m.in.: F. Casetti, L. Bohne, Antonioni and Hitchcock: Two Strategies of Narrative Investment, „SubStance: A Review of Theory and Literary Criticism” 1986, Vol. 15, No. 3, s. 69-86; J. Fawell, Stage Fright: Alfred Hitchcock's Fear of Acting, „Film Criticism" 2001, Vol. 26, No. 1, s. 25-41; J. Orr, Hitchcock and Hume Revisited: Fear, Confusion, and Stage Fright, „Film-Philosophy” 2007, Vol. 11, No. 1, s. 49-60.

8 Tomasz Kłys słusznie wskazuje, że pojęcie „refleksyjności” jest kalką angielskiego terminu reflexivity i francuskiego reflexivité. Kłys przekonuje, że bardziej adekwatnym polskim odpowiednikiem tego pojęcia byłaby „Zwrotność”. Zob. T. Kłys, Film fikcji i jego dominanty, Warszawa 1999, s. 231. Choć zgadzam się z zastrzeżeniami autora, będę używał pojęcia „refleksyjność” (a także „autorefleksyjność"), ponieważ zostało ono już dobrze zaadaptowane w polskiej humanistyce.

9 Zob. W. Browarny, Opowieści niedyskretne: formy autorefleksyjne w prozie polskiej lat dziewięćdziesiątych, Wrocław 2002, s. 29. 
i artystyczna, która tak przeorientowuje model wypowiedzi narracyjno-fabularnej, by zamiast przedstawianiu i porządkowaniu świata, służyła problematyzowaniu [...] fikcjonalności i językowości jego obrazu w dziele literackim i w każdej innej operacji intelektualnej"10. Trema nie jest oczywiście radykalnym dziełem samozwrotnym w stylu utworów Godarda, jednak, podobnie jak Okno na podwórze, zawiera elementy zarówno refleksyjne, jak i autorefleksyjne. Podczas gdy w arcydziele z 1954 roku kluczowy był motyw ram okiennych, symbolicznie odsyłający do ram kadru filmowego, w adaptacji powieści Selwyna Jepsona swego rodzaju lejtmotywem jest kurtyna. Trema jest bowiem filmem nie o voyeuryzmie, ale o relacji między kłamstwem a prawdą, fikcją a rzeczywistością.

Z uwagi na daleko posunięte odejście twórców od powieści Jepsona, trudno traktować Tremę jako przekład intersemiotyczny sensu stricto, jednak warto zwrócić uwagę na znaczące uzupełnienia i zmiany będące świadectwem reinterpretacji Uciekającego człowieka. Jak wiadomo, reżyser Ptaków (The Birds, 1963) podchodził dość niefrasobliwie do literackich oryginałów, traktował fabuły wybiórczo i zmieniał wymowę utworów. Można wnioskować, że twórca najczęściej szukał w literaturze jedynie luźnej inspiracji bądź szkieletów fabularnych, na których mógł budować własne audiowizualne opowieści ${ }^{11}$. Nie inaczej jest w przypadku Tremy, zrealizowanej na podstawie utworu pozbawionego większych walorów artystycznych i dość konwencjonalnego. Co znamienne, Uciekający człowiek, który po raz pierwszy ukazał się w formie odcinkowej w 1947 roku, po 1951 roku nie był już wydawany $^{12}$. Sam reżyser w następujący sposób wyjaśniał, dlaczego podjął się adaptacji kryminału: „[...] był w nim element, który mnie interesował:

10 Ibidem, s. 25.

11 „Kiedy podstawowa idea odpowiada mi - adaptuje ją, po czym natychmiast o niej zapominam i robię kino. Nie potrafiłbym panu opowiedzieć Ptaków Daphne du Maurier. Czytałem tę powieść [sic!] raz, w pośpiechu”. Następnie Hitchcock dodaje, dlaczego nie adaptuje arcydzieł: „Nie rozumiem, jak można łudzić się, że da się zawładnąć dziełem, wybitną powieścią, którą autor pisał trzy albo cztery lata i która określa sens jego życia”; F. Truffaut, Hitchcock / Truffaut, współpraca H. Scott, tłum., oprac. i posłowie T. Lubelski, Izabelin [cop. 2005], s. 63-64.

12 W 1948 roku Uciekajacy człowiek wyszedł w formie książkowej w Stanach Zjednoczonych i w Wielkiej Brytanii. W 1950 roku powieść została wydana pod 
możliwość nakręcenia historii o teatrze. Podobał mi się konkretnie taki pomysł: młoda dziewczyna, która chce zostać aktorką, musi się przebrać i zagrać swoją pierwszą rolę w prawdziwym życiu, prowadząc policyjne śledztwo"13. Lektura powieści Jepsona dowodzi jednak, że wątek sceniczny jest w oryginale jedynie marginalny i dopiero w adaptacji Hitchcocka motyw teatru staje się metaforą ogniskującą znaczenia całego dzieła.

Podstawowe zmiany w stosunku do powieści zostały wprowadzone już na etapie scenariusza, który został napisany przez żonę reżysera - Almę Reville, Whitfielda Cooka (odpowiedzialnego głównie za dialogi) oraz samego Hitchcocka, zawsze aktywnie uczestniczącego w tej fazie preprodukcji ${ }^{14}$. Wydaje się, że modyfikacje fabularne zostały spowodowane tyleż ograniczeniem czasowym przekazu filmowego, co troską o wiarygodność i spójność historii. Jepson przedstawia jednocześnie dwa wątki. Pierwszy związany jest z kradzieżą dokonaną przez główną bohaterkę, a zarazem narratorkę powieści, Eve, która włamuje się do domu ciotki, by zabrać niesprawiedliwie przywłaszczony przez krewną obraz, namalowany rzekomo przez Rembrandta. Po popełnieniu przestępstwa kobieta spotyka przypadkiem nieznajomego mężczyznę, Jonathana, co staje się początkiem drugiego wątku. Eve postanawia bowiem pomóc temu „uciekającemu człowiekowi”, niesłusznie oskarżonemu o zabicie męża swojej kochanki, znanej aktorki Charlotte. Protagonistka rozpoczyna prywatne śledztwo, zatrudnia się jako garderobiana aktorki i szuka dowodów na niewinność Jonathana. Twórcy Tremy zrezygnowali z zupełnie nieprzekonującego wątku kradzieży obrazu i skupili się na amatorskim śledztwie prowadzonym przez Eve, która próbuje oczyścić z zarzutów Jonathana.

tytułem Zabójca w zastępstwie (Killer by Proxy), a w 1951 ukazała się w tłumaczeniu francuskim jako Panique.

13 F. Truffaut, op. cit., s. 177.

14 Donald Spoto podaje, że nad wygładzeniem scenariusza pracowali także James Bridie i Ronald McDougall. D. Spoto, Alfred Hitchcock, tłum. J.S. Zaus, Warszawa 2000, s. 350. Warto dodać, że Trema była pierwszym dziełem reżysera wyprodukowanym przez wytwórnię Warner Brothers, choć realizowanym w Londynie. 
W kontekście zagadnienia autorefleksyjności od redukcji fabularnych znacznie istotniejsza jest jednak amplifikacja ${ }^{15}$ wątków związanych $\mathrm{z}$ teatrem. Choć Charlotte w powieści jest znaną aktorką, to żaden z fragmentów utworu Jepsona nie rozgrywa się w teatrze. Duża część akcji Uciekającego człowieka dzieje się w wiejskim domu należącym do ojca Eve, w filmie pojawiającym się zaledwie w jednej sekwencji. To właśnie w wiejskiej posiadłości główna bohaterka w finale powieści podstępnie nagrywa rozmowę z Charlotte i na żywo „transmituje” jej wyznanie zgromadzonym w domu gościom. W adaptacji, dla odmiany, aż cztery rozbudowane sceny rozgrywają się w przestrzeni (para)teatralnej ${ }^{16}$, a finałowy fortel głównej bohaterki także ma miejsce w „siedzibie Melpomeny”. Ponadto, inaczej niż w oryginale, Eve jest w filmie studentką Królewskiej Akademii Sztuki Dramatycznej (RADA) w Londynie, co nadaje postaci nowy wymiar. Jak bowiem wskazywał sam Hitchcock, rola garderobianej, odgrywana podczas prywatnego śledztwa, to dla aspirującej artystki swego rodzaju debiut aktorski, tyle że dokonujący się w realnym życiu. Amplifikacja wątków teatralnych nie jest czymś szczególnie zaskakującym na tle twórczości reżysera. Choć oprócz Tremy tylko Morderstwo (Murder!, 1930) rozgrywa się w środowisku aktorskim, to jednak kulminacje takich dzieł, jak 39 kroków (39 Steps, 1935), Człowiek, który wiedział za dużo (The Man Who Knew Too Much, 1934 i 1956) czy Rozdarta kurtyna (Torn Curtain, 1966), też mają miejsce na scenie $^{17}$. Fascynacja Hitchcocka Melpomeną może wydać się paradoksalna, zważywszy że eksplorujący filmowe środki reżyser był pochłonięty ideą

15 Amplifikacja to „wzmocnienie, podkreślenie, zaakcentowanie” w adaptacji elementu obecnego w pierwowzorze. M. Hendrykowski, Adaptacja jako przekład intersemiotyczny, „Przestrzenie Teorii” 2013, nr 2, s. 179.

$16 \mathrm{~W}$ teatrze (dwukrotnie), w szkole dramatycznej oraz podczas wystąpienia Charlotte na pikniku charytatywnym.

17 Jak zauważa Leslie Abramson: „Od najwcześniejszych brytyjskich filmów niemych Hitchcocka do jego ostatnich hollywoodzkich fabul, jego utwory przedstawiają świat pełen wykonawców (performers), role-playing’u i oszustw. Począwszy od jego pierwszego filmu, Ogrodu rozkoszy, niezliczeni wykonawcy wypełniają przestrzeń publiczną: tancerki z zespołu rewiowego, gwiazdy teatru, artyści muzyczni, piosenkarze, muzycy, artyści trapezowi, naganiacze $\mathrm{z}$ wesołych miasteczek [...], studenci aktorstwa i aktorzy [...]"; L.H. Abramson, Hitchcock and the Anxiety 
„Czystego” kina - i w tym sensie antyteatralny. Teatr intryguje jednak twórcę tyleż jako konwencja opowiadania, ile jako metonimia szeroko rozumianego spektaklu, jakim jest również przedstawienie filmowe (ale i samo życie).

Wraz z wątkami teatralnymi pojawia się w adaptacji nieobecny w oryginale motyw kurtyny. Choć Hitchcock nie należał do filmowców-erudytów, skrupulatnie analizujących symbolikę swoich dzieł, to jednak miał wyjątkową intuicję do tworzenia gęstych znaczeniowo, wizualnych metafor. Jednym z lejtmotywów twórczości reżysera jest zasłona oraz jej specyficzny rodzaj - kurtyna. Zasłona nieodparcie kojarzy się z psychoanalizą oraz $\mathrm{z}$ hermeneutyką podejrzeń. Ukrywanie się za zasłoną wynika często z chęci ucieczki od spojrzenia Innego. Kamera w filmach Hitchcocka zagląda za zasłonę i wkracza w prywatną przestrzeń bohaterów, pokazując to, co chcą ukryć $^{18}$. Motyw ten ma jednak w kinie reżysera także wymiar autorefleksyjny i służy obnażaniu ram przedstawienia. Wystarczy wspomnieć o początku Okna na podwórze, kiedy rolety okienne w domu Jeffa podnoszą się niczym kurtyna. Z jednej strony obraz ten może sugerować, że bohater traktuje rzeczywistość jak przedstawienie, z drugiej kreuje paralelę między pozycją mężczyzny a pozycją widza filmowego. Motyw kurtyny w sposób bezpośredni pojawia się w Morderstwie, opowiadającym o amatorskim śledztwie prowadzonym przez znanego brytyjskiego aktora. W finale kryminału mężczyzna całuje się z aktorką, którą dzięki prywatnemu dochodzeniu uratował od kary śmierci, jednak po chwili kurtyna opada i okazuje się, że była to wyłącznie scena ze spektaklu teatralnego wystawianego przez protagonistę. Ujawniając fikcjonalność przedstawienia teatralnego, Hitchcock zwraca uwagę na fikcjonalność samego filmu.

of Authorship, New York 2015, s. 99. Jeśli nie zaznaczono inaczej, wszystkie anglojęzyczne cytaty podaję w tłumaczeniu własnym - R.B.

18 Podobną funkcję zasłona pełni w Tremie. W scenie fałszywej retrospekcji, kiedy Charlotte po rzekomym zabiciu męża przychodzi do Jonathana, od razy mówi mężczyźnie, by ten zasłonił okna. Co znamienne, kiedy chwilę później Jonathan mówi bohaterce, by ta nie dała na scenie nic po sobie poznać i grała swoją rolę, bohaterka wychodzi z mroku - pełniącego rolę symbolicznej zasłony - w światło. Wyjście na zewnątrz, wyjście zza zasłony wiąże się z w Tremie z koniecznością udawania. 
Dla odczytania Tremy kluczowe znaczenie może mieć rama kompozycyjna filmu, przedstawiającą unoszącą się (w prologu) i opadającą (w finale) kurtynę. Dzieło Hitchcocka zaczyna się od obrazu kurtyny z dużym napisem „Safety Curtain”, widocznego na ekranie jeszcze przed pojawieniem się logo wytwórni (il. 1). Kurtyna oddziela w teatrze przestrzeń widzów od przestrzeni przedstawienia, jednak w prologu Tremy za unoszącą się zasłoną nie znajduje się wcale scena teatralna, ale świat zewnętrzny - jego „realność” zostaje podkreślona pojawieniem się w kadrze powszechnie rozpoznawalnego obiektu, jakim jest Katedra Świętego Pawła w Londynie (il. 2). Ten interesujący zabieg uruchamia serię pytań. Czy mamy do czynienia ze wstępną charakterystyką świata diegetycznego Tremy, w którym, jak się okaże, postaci grają także poza teatrem? A może Hitchcock wskazuje na fikcjonalność swojego dzieła i na wstępie podważa obiektywizm przekazu, co można byłoby rozpatrywać w kontekście późniejszego zastosowania narracji niewiarygodnej? Zabieg ten może wreszcie służyć komunikatowi o naturze bardziej ogólnej, mówiącemu, że świat zewnętrzny, świat widza, także nosi znamiona spektaklu.

Niezależnie od odpowiedzi na te pytania granica między światem fikcji a światem rzeczywistym zostaje w prologu Tremy zaburzona. Nie bez znaczenia jest również fakt, że kurtyna z prologu to tzw. safety curtain, zasłona, która ma w teatrze chronić publiczność przed pożarami ${ }^{19}$, odcinając ją od przestrzeni sceny. Można przyjąć, że na poziomie symbolicznym kurtyna chroni widzów przed światem fikcji, przed spektaklem, który oglądają. Borys Uspienski uznawał kurtynę za ramę, czyli granicę dzieła artystycznego, oddzielającą sztukę od rzeczywistości ${ }^{20}$. Wykorzystując motyw kurtyny odsłaniającej realny świat, Hitchcock już na wstępie zasugerował, że ramy będą w filmie zaburzane - jak się okaże, dotyczy to nie tylko świata diegetycznego, ale też narracji samego dzieła. W konsekwencji również i widz, wciągnięty w refleksyjną grę, zostanie pozbawiony symbolicznej „kurtyny

19 W dalszej części filmu pojawia się też humorystyczna wariacja na temat tego motywu. Jonathan, uciekając przed policją, chowa się w samochodzie i pokazuje dobijającym się do środka policjantom, że ma odporne szyby - widzimy wówczas zbliżenie z napisem „Safety Glass”.

20 B. Uspienski, Poetyka kompozycji. Struktura tekstu artystycznego i typologia form kompozycji, tłum. P. Fast, Katowice 1997, s. 201. 


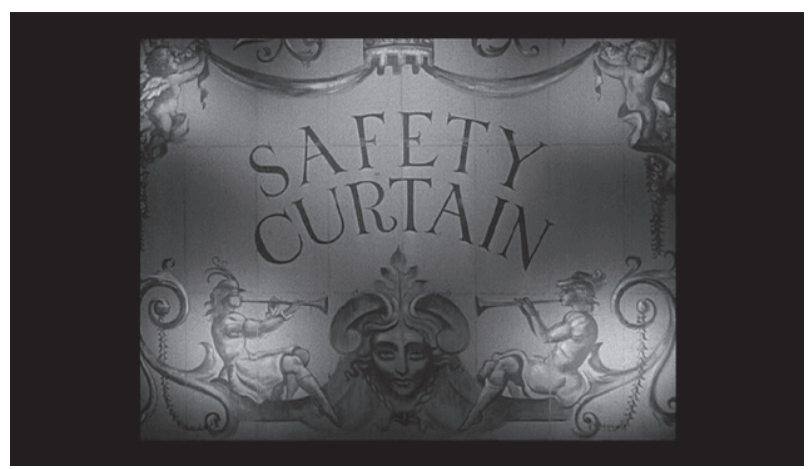

Il. 1. Pierwszy kadr Tremy. Napis „Safety Curtain” pojawia się jeszcze przed logo wytwórni Waner Brothers

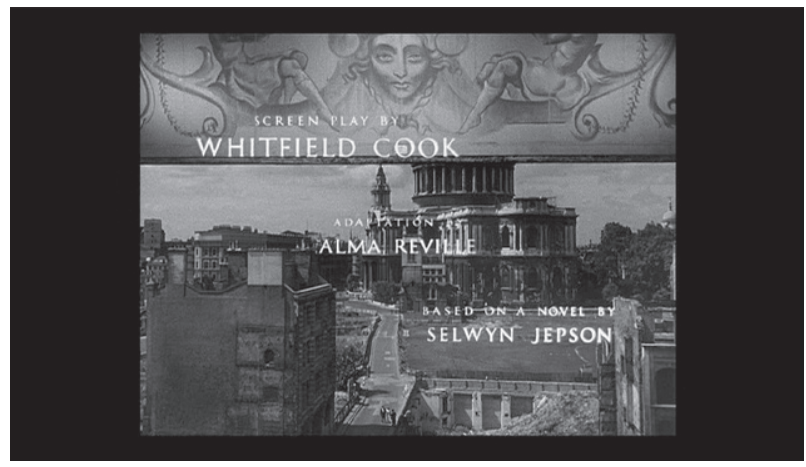

Il. 2. Kurtyna unosi się, ukazując scenerię Londynu z dobrze widoczną w tle Katedrą Świętego Pawła

ochronnej", która w kinie klasycznym pozwalała mu być biernym odbiorcą spektaklu. O ile jednak w Oknie na podwórze czy w Psychozie (Psycho, 1960) zaburzenia ramy mogły wytrącać widza ze „sfery komfortu”, o tyle Trema ma formę niemal komediową i jest autorefleksyjnym żartem.

Najprostszym zabiegiem autorefleksyjnym zastosowanym przez Hitchcocka są bezpośrednie odniesienia do teatru. Fabuła, w której tak istotne znaczenie ma motyw udawania kogoś innego, pozwala na sproblematyzowanie tematu gry - w teatrze, w filmie, ale też w życiu. Podczas gdy w Uciekającym człowieku pojawiają się dość nieliczne dialogi podejmujące 
temat aktorstwa ${ }^{21}$, w filmie działania bohaterów nieustannie porównywane są ze spektaklem teatralnym. Ojciec Eve, „Komandor” Gill, kieruje w stronę córki następujące słowa: „wszystko jest rolą w sztuce, odkąd połknęłaś bakcyla teatru”; „mamy fabułę, ciekawą obsadę, nawet kostium, nie bardzo nadający się do noszenia”; „[...] dajesz bardzo dobry występ. Szkoda, że nie masz widowni"22. Główna bohaterka odwzajemnia się tym samym, mówiąc ojcu m.in. „umierasz, żeby wejść do tej gry, i wiesz o tym”. Z kolei Jonathan oznajmia Charlotcie: „dopóki mam sukienkę, ja decyduję, ile potrwa to przedstawienie”, a inspektor Smith mówi z żalem do Eve: „sprytnie zagrałaś w taksówce”. Podczas gdy Eve i Charlotte "grają” w życiu zawodowym i prywatnym, postać „Komandora” można skojarzyć z figurą reżysera $^{23}$. W efekcie opowieść nabiera charakteru niemal metafikcjonalnego: bohaterowie są aktorami, intryga zostaje wyreżyserowana przez postaci, a przedmioty, takie jak poplamiona krwią suknia, pełnią jedynie funkcję rekwizytów.

Można uznać, że motyw odgrywania ról jest w Tremie znacznie istotniejszy od samej fabuły. Podczas gdy powieść Jepsona angażuje odbiorcę przede wszystkim wartką akcją ${ }^{24}$, głównym źródłem napięcia w adaptacji Hitchcocka jest niepewność, co do tego, czy (bądź w którym momencie) "grający" bohaterowie zostaną zdemaskowani. Działania wiodących postaci mają znamiona spektaklu i są wykonywane z myślą o konkretnych obserwatorach, a uwaga widza zostaje przekierowana $\mathrm{z}$ intrygi fabularnej na relacje między bohaterami. Kilkakrotnie w Tremie zdarza się sytuacja,

${ }^{21}$ Przykładowo, Freddy, kochanek Charlotte, mówi Eve, udającej przed nim aspirującą aktorkę: „Kiedy powiedziałem, że nie jesteś aktorką, nie miałem na myśli, że nie potrafisz grać. Wszystkie kobiety potrafią. To ich natura” („When I said you aren't an actress, I didn't mean you couldn't act. Most women can. It's the nature of them"). S. Jepson, Man Running, London 1948, s. 235.

22 Wszystkie cytaty z filmu przytaczam za tłumaczeniem zamieszczonym na płycie DVD: A. Hitchcock, Trema, reż. A. Hitchcock, Galapagos 2016.

${ }_{23}$ Zob. W.A. Drumin, Thematic and Methodological Foundations of Alfred Hitchcock's Artistic Vision, New York 2004, s. 232.

${ }^{24}$ Główna bohaterka Uciekającego człowieka między innymi podsłuchuje Charlotte i zakrada się do domu Freddy'ego, a w finale sama organizuje urządzenia do podsłuchiwania. 
w której postać A udaje kogoś przed postacią B, a jednocześnie jest obserwowana przez postać C, przed którą musi udawać kogoś jeszcze innego. Prowadzi to do multiplikacji ról i zapętlenia. Dobrym przykładem jest scena, w której Jonathan ucieka przed policją do siedziby Królewskiej Akademii Sztuki Dramatycznej i szuka schronienia na scenie, udając aktora i całując biorącą udział w próbie teatralnej Eve. Mężczyzna w tym momencie „gra granie" i jest podwójnym oszustem, ponieważ oszukuje zarówno policję (grając aktora), jak i Eve (grając niewinnego) ${ }^{25}$. Jeszcze większe zapętlenia pojawiają się w scenie festynu, która też nie występuje w powieści Jepsona. Główna bohaterka dla swoich znajomych pozostaje studentką aktorstwa Eve, dla Charlotte jest początkującą garderobianą Doris ${ }^{26}$, a dla poprzedniej garderobianej - ciekawską dziennikarką. W efekcie od intrygi kryminalnej ważniejsza staje się zintensyfikowana przez montaż gra spojrzeń i punktów widzenia, a nad poziomem akcji nadbudowane zostają refleksje na temat tożsamości postaci. Czy Eve i Charlotte kiedykolwiek przestają grać? Czy można oddzielić maskę od prawdziwej osobowości, grę od autentyzmu? Kładąc akcent na te zagadnienia, Hitchcock wykracza poza model hollywoodzkiego „kina-ruchu”, którego fundamentem jest czysta akcja ${ }^{27}$. Można zgodzić się z konstatacją Gilles’a Deleuze’a, że „w filmach Hitchcocka akcja, gdy jest już dana, zostaje dosłownie spowita w zespół relacji, które zmieniają jej temat, naturę, cel; nie chodzi o to, kto uruchomił akcję - co Hitchcock z pogardą nazywa whodunit („kto to zrobił”?) - ani o samą akcję - chodzi o zespół relacji, w które zostaje uwikłana sama akcja oraz ten, kto ją uruchomił”28. W Tremie jest to relacja między „aktorami” a ich „publicznością”, tymi, którzy grają, a tymi, którzy percypują „przedstawienie”.

Co istotne, problem tożsamości „aktorów” znajduje odbicie także na wyższym, ponadfabularnym poziomie. W jednej ze scen Eve (grana przez

25 Zob. W.A. Drumin, Thematic and Methodological Foundations of Alfred Hitchcock's Artistic Vision, New York 2004, s. 232.

${ }^{26}$ Ubraną dodatkowo w strój poprzedniej garderobianej z wyszytym imieniem „Nellie”. Jakby tego było mało, Charlotte nazywa niekiedy swoją nową służącą imieniem „Phyllis” lub „Mavis”.

27 Nawiązuję do kategorii Gilles’a Deleuze’a. Zob. G. Deleuze, Kino. 1: Obraz-ruch. 2: Obraz-czas, tłum. J. Margański, Gdańsk 2008.

28 Ibidem, s. 212. 
Jane Wyman), która po raz pierwszy idzie do Charlotte jako jej garderobiana, powtarza sobie na ulicy wyuczoną formułkę: „Nazywam się Doris Tinsdale. Przysyła mnie Nellie”. Dokładnie w tym momencie przechodzący ulicą mężczyzna odwraca się i lustruje wzrokiem kobietę, dokonującą tak osobliwej autoprezentacji. Osobnikiem tym jest oczywiście sam Alfred Hitchcock (il. 3). Słynne wystąpienia twórcy we własnych filmach są „stałym hitchcockowskim sposobem igrania $\mathrm{z}$ »ramą" przedstawienia”29 $\mathrm{i}$ bywają klasyfikowane jako przykład metalepsy autorskiej ${ }^{30}$. Pojawienie się Hitchcocka w Tremie ma jednak szczególny charakter - reżyser bardzo rzadko filmowany był w swoich dziełach w tak bliskich planach ${ }^{31} \mathrm{i}$ jako postać nigdy nie reagował w żaden sposób na zachowanie protagonistów. Wydaje się, że twórca występuje w adaptacji powieści Jepsona w nieprzypadkowym momencie; dzięki przywołaniu płaszczyzny metanarracyjnej słowa bohaterki zostają wzbogacone o nowy kontekst: oto bowiem Alfred Hitchcock przygląda się Jane Wyman, która gra aktorkę Eve, wcielająca się w postać garderobianej Doris. Reżyser uwydatnia w ten sposób paralelę między treścią filmu a mechanizmami jego tworzenia - udawanie jest w Tremie zarazem środkiem kreowania opowieści filmowej, jak i jej tematem. Wprowadzając poziom metanarracyjny, Hitchcock łamie jedną z zasad kina klasycznego, mówiącą o tym, że „nie wolno sygnalizować faktu obecności ekipy kręcącej film ani produkcji filmu"32.

Reżyser ponadto obnaża iluzję spektaklu poprzez grę punktami widzenia oraz odwołanie się do kodów filmowych. Warto w tym kontekście zwrócić uwagę zwłaszcza na sposób przedstawienia granej przez Marlenę Dietrich Charlotte, która dwukrotnie pokazywana jest w Tremie podczas swych występów muzycznych. Przestrzeń sceniczna wypełnia w niektórych ujęciach cały kadr, a widzowie filmu mogą się wówczas poddać magii przedstawienia.

29 M. Karkiewicz, Metalepsa jako strategia narracyjna w dziełach literackich i filmowych (analiza zjawiska na wybranych przykładach), „Załącznik Kulturoznawczy” 2015, nr 2, s. 396.

30 Ibidem.

${ }^{31}$ Hitchcock jest pokazywany frontalnie w tak bliskim planie chyba jeszcze tylko w Zagranicznym korespondencie (Foreighn Correspondent, 1940), w Złodzieju w hotelu (To Catch a Thief, 1955) i w Marnie (1965).

32 M. Przylipiak, op. cit., s. 123. 


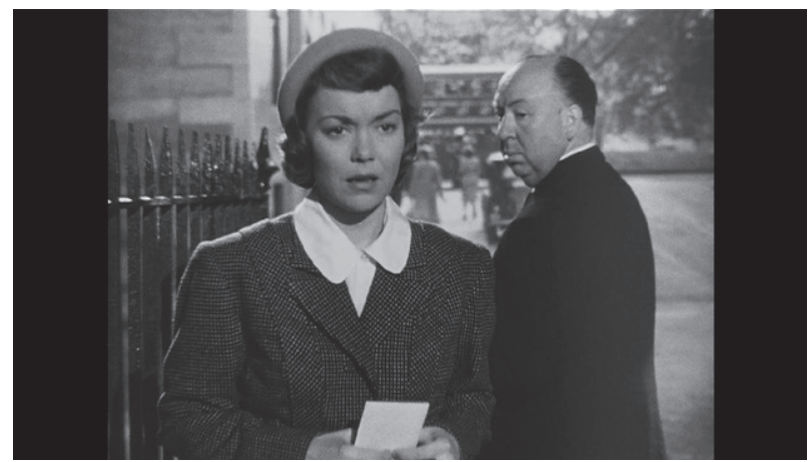

\section{Il. 3. Cameo Alfreda Hitchcocka}

W innych momentach scena teatralna filmowana jest jednak zza zasłony (będącej symbolicznym wariantem motywu kurtyny) bądź zza kuluarów, co uwydatnia ramy spektaklu i może służyć deziluzji (il. 4). Niekiedy montaż zestawia punkt widzenia zachwyconej publiczności z zakulisowymi punktami widzenia Eve, która dzięki wiedzy zdobytej na temat Charlotte może zdystansować się do spektaklu wielkiej gwiazdy. Pokazywanie występów scenicznych zza kulis nie jest oczywiście w kinie niczym wyjątkowym, jednak Hitchcock obnaża nie tylko ramy scenicznego, ale też filmowego przedstawienia, biorąc niejako w cudzysłów wizerunek postaci. Ogólna charakterystyka Charlotte została zaczerpnięta z powieści Jepsona, gdzie jest ona spragnioną poklasku aktorką, która pragnie mieć dla siebie publiczność zarówno na scenie, jak i w życiu prywatnym ${ }^{33}$. Konieczność udawania kobiety pogrążonej w żałobie znacznie krępuje swobodę bohaterki, jednak w Uciekającym człowieku poskramia ona swoje ego, by przekonująco wypaść $\mathrm{w}$ roli wdowy ${ }^{34}$. Twórcy Tremy rozwijają ten wątek, ale w znaczący sposób

33 „To prawda, że była silną, samolubną i w pełni profesjonalną osobą, ale prawdą jest również, że nie mogła być szczęśliwa, dopóki na scenie obok niej nie pojawił się mężczyzna, który razem z nią grał, stymulował ją i dzielił jej emocje”. („It was true that she was a strong-minded, selfish and utterly competent person, but it was also true that she could not be happy unless there was a man on the stage with her, to play the scene with her, to stimulate, share and match her emotions"). S. Jepson, op. cit., s. 177.

34 Zob. ibidem, s. 148. 


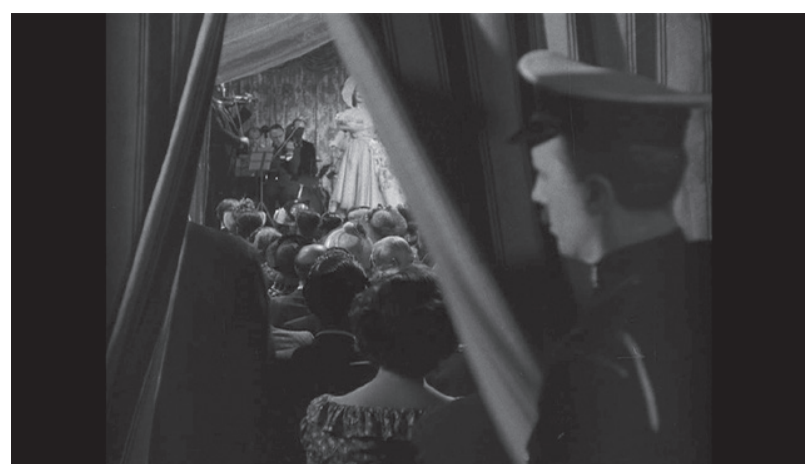

Il. 4. Podkreślanie ram spektaklu - wystapienie Charlotte

modyfikują charakter postaci - filmowa Charlotte nie dba po śmierci męża o pozory, chce jak najszybciej występować na scenie i nawet w żałobnym ubraniu pragnie wyglądać atrakcyjnie. Co najważniejsze, bohaterka zostaje obdarzona osobowością Marleny Dietrich, której Hitchcock - zazwyczaj wyjątkowo niechętny wobec artystycznych inicjatyw aktorów - pozwolił współreżyserować sceny z jej udziałem ${ }^{35}$. Charlotte, w Tremie pokazywana przeważnie w światłocieniu, w centrum kadru, w wystudiowanych, teatralnych pozach (il. 5), a czasem także w dużych zbliżeniach, zawsze skupia na sobie uwagę kamery.

Również w scenach rozgrywających się poza teatrem Dietrich jest pokazywana w wystylizowany sposób, podobnie jak w filmach Josefa von Sternberga. Widzowie mogą skojarzyć postać Charlotte z wcześniejszymi bohaterkami granymi przez aktorkę, zwłaszcza z Lolą z Błękitnego Anioła (Der blaue Engel, 1930), i uznać ją za typową femme fatale. W finale filmu okazuje się jednak, że choć Charlotte być może w jakiś sposób sprowokowała zbrodnię, to jednak nie ona jest morderczynią. Jak zauważa Tania Modleski, Hitchcock daje do zrozumienia, że historia „oparta została na męskim kłamstwie [Jonathana - przyp. R.B.] - a dokładniej na kłamstwie na temat kobiecej winy, które napędza maszynerię patriarchalnego kina"36. Inaczej niż Jepson, reżyser nie ogranicza się do ukazania „spektaklu” odgry-

35 D. Spoto, op. cit., s. 352.

36 T. Modleski, The Women Who Knew Too Much. Hitchcock and Feminist Theory, New York - London 2016, s. 119. 


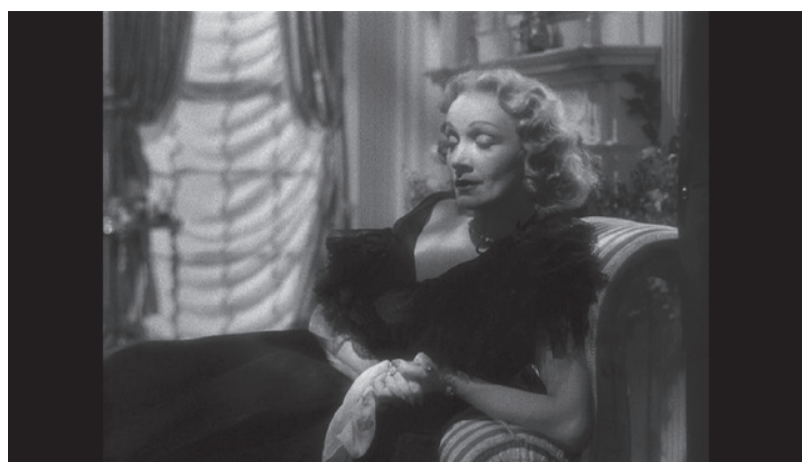

Il. 5. Charakterystyczny sposób przedstawiania Charlotte, granej przez Marlenę Dietrich

wanego przez Charlotte przed innymi bohaterami, ale, grając z kodem kina klasycznego, rozszerza ten motyw na poziom metanarracyjny. Hitchcock obnaża konwencjonalność ugruntowanego w kinie obrazu Dietrich i sugeruje, że jest on wyłącznie złudnym przedstawieniem.

Najszerzej komentowanym zabiegiem autorefleksyjnym zastosowanym w Tremie jest jednak słynne „kłamstwo” narracyjne. Oryginalność zabiegu zastosowanego przez Hitchcocka staje się szczególnie widoczna na tle porównania z powieścią, która przedstawiona została za pomocą konwencjonalnej, pierwszoosobowej narracji Eve. Co ciekawe, narracja Uciekajacego człowieka jest niekiedy podwójnie zapośredniczona, gdyż Eve przedstawia również wydarzenia, które zna wyłącznie z relacji Jonathana. Ponieważ we fragmentach tych zarówno przebieg akcji, jak i odczucia bohaterów zostają drobiazgowo opisane, można się zastanawiać, skąd narratorka czerpie aż tak rozległą wiedzę, jednak status epistemologiczny instancji narracyjnej nie zostaje w żaden sposób sproblematyzowany ${ }^{37}$. Bardzo symptomatyczny jest komentarz Eve na temat historii opowiedzianej przez Jonathana:

Z początku opowieść była nieskładna. Stała się jednak szczegółowa i spójna, kiedy doszedł do wydarzeń ostatniej nocy, kiedy to ona [Charlotte - przyp. R.B.] zadzwoniła do drzwi jego mieszkania. Wtedy ujawniła się precyzyjność

37 We fragmentach przedstawiających historię Jonathana nie zachodzi formalna zmiana narratora, jednak narracja jest zobiektywizowana - zdania pisane w pierwszej osobie właściwie się w tej części nie pojawiają. 
charakterystyczna dla obiektywnego umysłu. On niczego nie pomijał i mogłam zobaczyć sceny, tak jak zostały odegrane ${ }^{38}$.

Choć relacja z wizyty Charlotte u Jonathana została podwójnie zapośredniczona (przez Jonathana i przez Eve), to jednak autor symuluje obiektywność przekazu i uwiarygodnia narrację za pomocą chwytu retorycznego.

Aby w „fotograficznym” medium filmowym stworzyć wrażenie, że retrospekcja została przedstawiona w sposób naoczny, z „precyzją obiektywnego umysłu” (the precision of an objective mind), tak że „nic nie zostało pominięte" (leaving out nothing), nie trzeba uciekać się do podobnych zabiegów retorycznych. Choć w kinie klasycznym pojawiały się retrospekcje wprowadzane przez bohaterów-narratorów, którym nierzadko towarzyszył subiektywny komentarz spoza kadru, to jednak narracja wizualna pozostawała zobiektywizowana - bohater mógł kłamać, ale obraz był zazwyczaj zgodny z rzeczywistą wersją zdarzeń. Alfred Hitchcock jako jeden z pierwszych twórców kina amerykańskiego ostentacyjnie burzy w Tremie tę zasadę. W dziele z 1950 roku nie tylko narracja przedstawiona w filmie (wersja zdarzeń Jonathana), ale też narracja samego filmu (rozumiana jako sposób ukazania opowieści za pomocą środków audiowizualnych) wprowadza widza w błąd. Nie dość, że kłamstwo mężczyzny zostaje zwizualizowane, to jeszcze sekwencja ta ukazywana jest za pomocą względnie przezroczystej narracji i nie ma w niej żadnych stylistycznych wskazówek (np. w postaci deformacji obrazu czy dźwięku), że perspektywa opowiadającego mężczyzny może być zaburzona, niepełna bądź fałszywa ${ }^{39}$. W retrospekcji pojawia się kilka ujęć subiektywnych z punktu widzenia Jonathana, które jednak

38 „At first the story was disjointed. But it became detailed and connected when it reached last night, when she rang the bell of his flat. The precision of an objective mind showed clearly then. He was leaving out nothing and I could see the scenes as they had been played"; S. Jepson, op. cit., s. 69.

39 W Tremie można jednak odnaleźć subtelne tropy wskazujące na to, że osobowość Jonathana jest zaburzona. W scenie retrospekcji rozmawiający przez telefon z matką Eve mężczyzna pokazywany jest na tle surrealistycznego obrazu przedstawiającego m.in. skręcony spiralny budynek. Jak zauważa Michael Walker, obraz ten koresponduje ze zwichniętą psychiką bohatera. Walker wskazuje na znaczącą funkcję obrazów malarskich także w innych dziełach Hitchcocka. Zob. M. Walker, Paintings, [w:] idem, Hitchcock's Motifs, Amsterdam 2005, s. 327-329. 
tylko wzmacniają wiarygodność historii, ponieważ sprawiają, że widz silniej utożsamia się z bohaterem. W finale filmu okazuje się, że przebieg zdarzeń wyglądał zupełnie inaczej niż w opowieści - w rzeczywistości to Jonathan zabił męża Charlotte. Scenarzyści Tremy bardzo mocno przekształcają fabułę utworu Jepsona, w której to sadystyczny aktor Freddy - inny kochanek Charlotte - dokonał morderstwa.

Substytucja ta jest bardzo istotna w kontekście tematu filmu, jakim jest gra i udawanie. Okazuje się, że Jonathan, podobnie jak inne postaci, cały czas oszukiwał, a jego tożsamość pozostawała ukryta. Co najważniejsze jednak, podważona zostaje nie tylko wiarygodność bohatera, ale też wiarygodność samej narracji ${ }^{40}$, niejako wspierającej kłamstwo postaci ${ }^{41}$. Tego rodzaju chwyty Tomasz Kłys nazywa „poetyką negatywną”, która polega „na podważeniu wewnątrz dzieła ontycznego lub logicznego statusu (modalności) świata przedstawionego" ${ }^{\prime 2}$. Poetyka negatywna ma wymiar autorefleksyjny, ponieważ demaskuje fikcjonalność dzieła (bądź jego części) i ogniskuje

${ }^{40}$ Niektórzy badacze, np. Jacek Ostaszewski, używają w odniesieniu do filmów takich jak Trema zapożyczonego z literaturoznawstwa pojęcia „narratora niewiarygodnego". Zob. J. Ostaszewski, Narrator niewiarygodny w filmie fabularnym, „Kwartalnik Filmowy” 2010, nr 71-72, s. 60-74. Odrzucam jednak ten termin, mając na względzie istotne różnice pomiędzy narratorem literackim a instancją narracyjną w filmie. O kontrowersjach związanych z pojęciem "narratora” w filmie zob. m.in. M. Przylipiak, Narrator literacki, „narrator” filmowy, [w:] Studia Filmoznawcze, t. 9: Problemy poznawania dzieła filmowego, red. J. Trzynadlowski, Wrocław 1990. Pojęcia „bohater-narrator” używam w sensie przenośnym - to bohater, który opowiada w filmie jakąś historię.

${ }^{41}$ Peter Verstraten opisuje tego rodzaju sytuację, używając pojęcia „współwinnego narratora wizualnego" (complicit visual narrator). Filmoznawca określa tym mianem zewnętrzną, ekstradiegetyczną instancję narracyjną, która przedstawia wydarzenia zgodnie z tym, jak widzi bądź przedstawia je postać. Zob. P. Verstraten, Film Narratology, Toronto 2009, s. 113-115. Odrzucam jednak pojęcie „narratora” używane w odniesieniu do instancji narracyjnej w filmie.

42 T. Kłys, Poetyka negatywna w filmie: Zarys problematyki, [w:] Studia Filmoznawcze, t. 14: Film: symbol i tożsamość, red. J. Trzynadlowski, Wrocław 1992, s. 158. Autor inspiruje się literaturoznawczym pojęciem wprowadzonym przez Artura Sandauera. Zob. A. Sandauer, Samobójstwo Mitrydatesa, [w:] idem, Pisma zebrane, t. 2: Studia historyczne i teoretyczne, Warszawa 1985, s. 498-502. 
uwagę widza na samej narracji. „Kłamstwo” narracyjne zastosowane przez Hitchcocka zwraca uwagę na schematyczność kina klasycznego, w którym retrospekcje wyłącznie na mocy konwencji przedstawiały obiektywny bieg wydarzeń. Co ciekawe, właśnie przez kłamliwą retrospekcję Trema była przez lata odrzucana zarówno przez krytyków, jak i przez publiczność. W konsekwencji również i Hitchcock, który sam nalegał na to rozwiązanie (co zresztą poróżniło go ze współscenarzystami ${ }^{43}$ ), żałował później, że zdecydował się na tę sekwencję $e^{44}$. Od końca lat 90. kłamstwa narracyjne stanowią jeden z podstawowych chwytów w niezwykle popularnych współcześnie filmach-łamigłówkach (puzzle-films), takich jak Podejrzani (The Usual Suspects, 1995) Bryana Singera, i dopiero z perspektywy wielu lat można docenić prekursorstwo Hitchcocka. Oczywiście współczesne „narracje schizofreniczne” są znacznie bardziej powikłane od Tremy, jednak reżyser, łamiąc zasadę obiektywizmu kina klasycznego ${ }^{45}$ i podejmując z widzem grę nie tylko na poziomie fabularnym, ale też narracyjnym, wyraźnie zapowiada dużo późniejszy nurt. Hitchcock podważa iluzję obiektywności „fotograficznego” medium filmowego i pokazuje, że „styl przezroczysty” jest w kinie klasycznym elementem konwencji, a nie gwarantem wiarygodności przedstawianych wydarzeń.

Podsumowując - wydaje się, że zabiegi stosowane przez Hitchcocka w Tremie można uznać za przejaw autorefleksyjności. Przedmiotem refleksji

${ }^{43}$ Zob. P. McGilligan, Alfred Hitchcock: życie w ciemności i petnym świetle, tłum. J. Matys, A. i A. Nermerowie, I . Stąpor, Warszawa 2005, s. 539.

44 Hitchcock mówił w rozmowie z François Truffautem: „Przyznam się panu: zrobiłem w tej historii coś, na co nigdy nie powinienem był sobie pozwolić... retrospekcję, która była kłamstwem. [...] W filmach bez problemu akceptujemy fakt, że ktoś opowiada fałszywą historię. Bez trudności akceptujemy również to, że postać opowiada jakieś minione wydarzenie i że ilustruje je retrospekcja, tak jakby to wydarzenie rozgrywało się na naszych oczach. W takim razie dlaczego nie moglibyśmy również przedstawić kłamstwa wewnątrz retrospekcji?”; F. Truffaut, op. cit., s. 177-178.

45 Jak pisze Mirosław Przylipiak, „kino klasyczne zdawało się raczej pokazywać zdarzenia niż opowiadać o nich", a występowanie bohaterów-narratorów - pośredników między odbiorcami a wydarzeniami - było regulowane rozmaitymi ograniczeniami. M. Przylipiak, Kino stylu zerowego..., op. cit., s. 112. 
nie jest co prawda język filmowy sensu stricto, ale granie ról, oszukiwanie, fikcjonalność, a zatem elementy konstytuujące także przekaz filmowy. Porównując adaptację z Uciekającym mężczyzną, można dostrzec że reżyser konsekwentnie rozwija, redukuje bądź modyfikuje elementy literackiego oryginału, by wzbogacić opowieść o aspekt autorefleksyjny. Hitchcock usuwa wątki fabularne niezwiązane bezpośrednio $\mathrm{z}$ teatrem, przenosi akcję kluczowych momentów do „siedziby Melpomeny” i dodaje sceny rozgrywające się podczas przedstawień scenicznych. Porównania bohaterów do aktorów grających na scenie, występujące okazjonalnie już w Uciekającym człowieku, $\mathrm{w}$ Tremie stają się lejtmotywem i pojawiają się w postaci rozmaitych gier słownych. Opowieść zostaje wzbogacona też o wizualny lejtmotyw kurtyny (wraz z jego symbolicznymi wariantami), który pojawia się już w ramie kompozycyjnej filmu i podkreśla, że mamy do czynienia ze spektaklem. Wątki autorefleksyjne znajdują w Tremie wyraz na wielu płaszczyznach - nie tylko w fabule, dialogach i obrazie, ale też w samej narracji filmu. Podczas gdy Jepson przedstawia wydarzenia w sposób zobiektywizowany i za pomocą chwytów retorycznych uwiarygadnia narrację, Hitchcock stosuje poetykę negatywną. W efekcie wątki autorefleksyjne, jedynie śladowo obecne w powieści Jepsona, stają się dominantą poetyki Tremy. Można przyznać, że pomiędzy światem diegetycznym a narracją filmu zachodzi relacja zwierciadlana - oszukiwani są nie tylko bohaterowie, którzy patrzą na odgrywane przed nimi „przedstawienia”, ale także widzowie oglądający przedstawienie filmowe.

Hitchcock zawsze zainteresowany był autorefleksyjnością - wykorzystywanie metafor teatralnych, pojawianie się we własnych dziełach czy branie w cudzysłów konwencji filmowych to cechy charakterystyczne dla wielu dzieł „mistrza suspensu”. Choć filmy reżysera Okna na podwórze bywają podawane jako przykład precyzyjnie skonstruowanych klasycznych opowieści, to jednak najbardziej interesujące wydają się w nich znaczenia komunikowane ponad poziomem fabularnym. Hitchcock łamie wiele zasad kina klasycznego - wprowadza do filmów poziom metanarracyjny, podważa zasadę obiektywizmu i podejmuje refleksję nad zasadami funkcjonowania widowiska filmowego. Choć w odróżnieniu od twórców modernistycznych w stylu Godarda brytyjsko-amerykański reżyser nie próbuje niszczyć filmowej reprezentacji i dekonstruować gatunków, to jednak, jak zauważa Krzysztof Loska, jego filmy ujawniają „dwuznaczność 
i niestabilność wszelkich systemów, prowadzą "podwójną grę«, polegająca na równoczesnym przyjmowaniu i podważaniu konwencji gatunkowych, obnażaniu ideologii, sposobów konstruowania opowieści filmowej (napięcie między "przezroczystością " narracji klasycznej a "samoświadomością" narracji artystycznej)" ${ }^{\prime 6}$. Co najistotniejsze z perspektywy odbiorczej, reżyser snuje refleksję nad kinem, nie zabierając widzowi przyjemności oglądania utrzymana w komediowej formie Trema jest tego najlepszym przykładem. Dzięki atrakcyjności formy Hitchcock nie podzielił losu tych modernistów, którzy „przedawkowali dozę samoświadomości”47 i zaczęli kręcić dzieła nieangażujące odbiorców.

W odróżnieniu od radykalnych twórców modernistycznych reżyser Tremy nie poprzestaje poza tym na badaniu autonomicznych cech medium, ale wskazuje na mieszanie się sztuki i życia. W adaptacji powieści Jepsona Hitchcock ujawnia nie tylko fikcjonalność przekazu filmowego, lecz również rolę fikcji, oszustwa i gry w rzeczywistości. Zdaniem socjologów trema może powstawać wtedy, kiedy aktor boi się, że jakiś błąd lub skaza zakwestionuje tożsamość, którą chce przybrać na scenie ${ }^{48}$. Tytuł filmu można w tym kontekście odnieść także do pozascenicznego życia bohaterów, którzy boją się demaskacji w realnym świecie. Drobny błąd wystarczy, by postaci, nakładające na siebie maski, straciły wiarygodność w swoich rolach. „Aktorstwo”, udawanie, role-playing są jednak dla bohaterów Tremy nie tylko środkiem pozwalającym na ukrycie tożsamości, ale też metodą dochodzenia do prawdy oraz sposobem samorealizacji. Na przykład Charlotte rozkoszuje się przyjętą przez siebie rolą, a w sposobie jej bycia można dostrzec kampową wręcz przesadę. Z kolei Eve, która pozornie wciela się w rolę Doris, żeby udowodnić niewinność Jonathana, realizuje poprzez grę także podświadome pragnienia. Można wnioskować, że studentką aktorstwa kieruje tyleż miłość do Jonathana, co chęć rywalizacji z wielką gwiazdą Charlotte zarówno

${ }^{46}$ K. Loska, Hitchcock - autor wśród gatunków, Kraków 2002, s. 9.

47 Zob. na ten temat: T. Kłys, Film fikcji i jego dominanty, op. cit., s. 231. Kłys formułuje te słowa przede wszystkim w odniesieniu do Stanu rzeczy (Der Stand der Dinge, 1982) Wima Wendersa.

48 S. Lyman, M. Scott, Stage Fright and the Problem of Identity, [w:] idem, A Sociology of the Absurd, General Hall, Inc., New York 1989, s. 69. 
w realnym życiu, jak i na polu gry aktorskiej ${ }^{49}$. Sztuka i życia odbijają się w Tremie na wiele sposobów.

Granice między prawdziwymi tożsamościami a odgrywanymi rolami, prawdą a kłamstwem, autentyzmem a graniem, rzeczywistością a fikcją są w dziele Hitchcocka nieustannie zaburzane ${ }^{50}$. Nic dziwnego więc, że motyw kurtyny, która pojawia się na początku i na końcu filmu, odgrywa w Tremie tak istotną rolę. Co znamienne, Jonathan ginie na styku dwóch przestrzeni - przestrzeni realnej i przestrzeni fikcji - kiedy w finale zostaje przygnieciony przez kurtynę bezpieczeństwa (il. 6). Można jednak przyjąć, że kurtyna - a więc rama dzieła artystycznego - to również reprezentacja granicy między nami, widzami, a samym filmem. Hitchcock zaburza ją już w prologu, kiedy za zasłoną ukazuje się naszym oczom nie scena, lecz realna przestrzeń Londynu. Symbolicznie zaburzając ramę, reżyser zdaje się sugerować, że przedstawienie, które oglądamy, dotyczy także nas samych. My także funkcjonujemy na co dzień w przestrzeni, w której umiera Jonathan - na styku fikcji i realności, w tym sensie, że zmyślenie i gra są stałym elementem naszego życia. Autorefleksja na temat sztuk fabularnych łączy się zatem w adaptacji powieści Jepsona z refleksją nad ludzką tożsamością. Ignorowana przez filmoznawców Trema jest dobrym przykładem tego, jak reżyser, przyjmując lekką konwencję komedii kryminalnej, podejmuje nie tylko zagadnienie fikcjonalności dzieła filmowego, ale też temat gry, zmyślenia i kłamstwa, które współtworzą nasze życie.

49 Interpretacja ta znajduje potwierdzenie w zastosowanych technikach filmowych. W większości scen przedstawiających rozmowy Charlotte i Eve/Doris wielka aktorka rzuca tylko ukradkowe spojrzenia w stronę garderobianej, stojącej zazwyczaj u jej boku. Kiedy w finale filmu Eve demaskuje Charlotte, rozmowa obydwu kobiet jest pokazywana za pomocą techniki ujęcie - przeciwujęcie, będącej znakiem równości między postaciami.

${ }^{50}$ Zaburzanie ram i granic - między narracją zobiektywizowaną a zsubiektywizowaną, między realnością a fikcją, między „prawdziwą” tożsamością a rolą, między przestrzenią widza a przestrzenią spektaklu - to jedna z najważniejszych cech poetyki Tremy. 


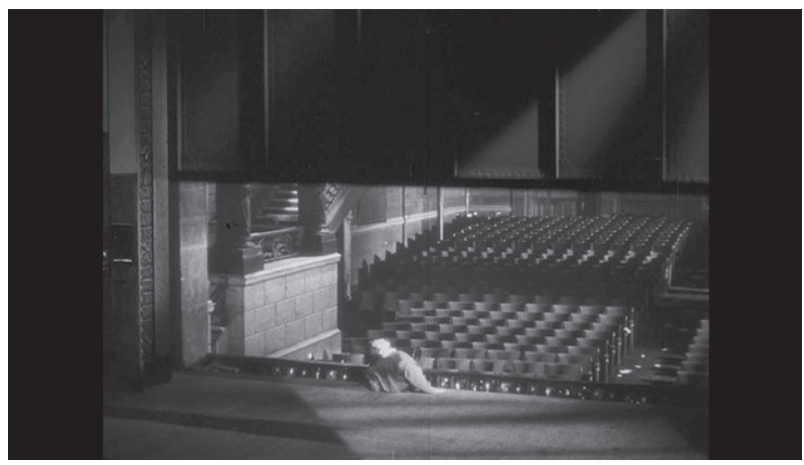

Il. 6. Śmierć Jonathana na styku dwóch przestrzeni

\section{Bibliografia}

Leslie Abramson, Hitchcock and the Anxiety of Authorship, Palgrave Macmillan, New York 2015.

Wojciech Browarny, Opowieści niedyskretne: formy autorefleksyjne w prozie polskiej lat dziewięćdziesiątych, WUWr, Wrocław 2002.

Francesco Casetti, Luciana Bohne, Antonioni and Hitchcock: Two Strategies of Narrative Investment, „SubStance: A Review of Theory and Literary Criticism" 1986, Vol. 15, No. 3.

Gilles Deleuze, Kino. 1: Obraz-ruch. 2: Obraz-czas, tłum. J. Margański, Słowo/obraz terytoria, Gdańsk 2008.

William Drumin, Thematic and Methodological Foundations of Alfred Hitchcock's Artistic Vision, Edwin Mellen Press, New York 2004.

John Fawell, Stage Fright: Alfred Hitchcock's Fear of Acting, „Film Criticism” 2001, Vol. 26, No. 1.

Thomas Hemmeter, Hitchcock's Narrative Modernism: Ironies of Fictional Time, [w:] A Companion to Hitchcock, eds. T. Leitch, L. Poague, Wiley-Blackwell, Malden, MA-Oxford.

Marek Hendrykowski, Adaptacja jako przekład intersemiotyczny, „Przestrzenie Teorii" 2013, nr 2.

Selwyn Jepson, Man Running, Hurlingham Books, London 1948.

Magdalena Karkiewicz, Metalepsa jako strategia narracyjna w dziełach literackich i filmowych (analiza zjawiska na wybranych przykładach), „Załącznik Kulturoznawczy” 2015, nr 2. 
Kino klasyczne, red. T. Lubelski, I. Sowińska, R. Syski, TAiWPN Universitas, Kraków 2011.

Tomasz Kłys, Film fikcji i jego dominanty, WN Semper, Warszawa 1999.

Tomasz Kłys, Poetyka negatywna w filmie: Zarys problematyki, [w:] Studia

Filmoznawcze, t. 14: Film: symbol i tożsamość, red. J. Trzynadlowski, WUWr, Wrocław 1992.

András Kovács, Screening Modernism. European Art Cinema: 1950-1980 (Cinema and Modernity), The University of Chicago Press, Chicago - London 2007. Krzysztof Loska, Hitchcock - autor wśród gatunków, Rabid, Kraków 2002.

Stanford M. Lyman, Marvin B. Scott, Stage Fright and the Problem of Identity, [w:] idem, A Sociology of the Absurd, General Hall, Inc., New York 1989.

Patrick McGilligan, Alfred Hitchcock: życie w ciemności i pełnym świetle, tłum. J. Matys, A. i A. Nermerowie, I. Stąpor, WK „Twój Styl”, Warszawa 2005.

Tania Modleski, The Women Who Knew Too Much. Hitchcock and Feminist Theory, Routledge - Taylor \& Francis Group, New York - London 2016.

John Orr, Hitchcock and Hume Revisited: Fear, Confusion, and Stage Fright, „Film-Philosophy" 2007, Vol. 11, No. 1.

Jacek Ostaszewski, Historia narracji filmowej, TAiWPN Universitas, Kraków [cop. 2018].

Jacek Ostaszewski, Narrator niewiarygodny w filmie fabularnym, „Kwartalnik Filmowy" 2010, nr 71-72.

Jacek Ostaszewski, Nowe kino, nowa narracja, [w:] Kino epoki nowofalowej, red. T. Lubelski, I. Sowińska, R. Syska, TAiWPN Universitas, Kraków 2015.

Mirosław Przylipiak, Kino stylu zerowego. Dwadzieścia lat później, wyd. 2 popr. i rozsz., GWP, Sopot 2016.

Mirosław Przylipiak, Narrator literacki, „narrator” filmowy, [w:] Studia Filmoznawcze,

t. 9: Problemy poznawania dzieła filmowego, red. J. Trzynadlowski, WUWr, Wrocław 1990.

Artur Sandauer, Samobójstwo Mitrydatesa, [w:] idem, Pisma zebrane, t. 2: Studia historyczne i teoretyczne, Spółdzielnia Wydawnicza Czytelnik, Warszawa 1985. Donald Spoto, Alfred Hitchcock, tłum. J.S. Zaus, Alfa, Warszawa 2000.

François Truffaut, Hitchcock / Truffaut, współpraca H. Scott, tłum., oprac. i posłowie T. Lubelski, „Świat Literacki”, Izabelin 2005.

Boris Uspienski, Poetyka kompozycji. Struktura tekstu artystycznego i typologia form kompozycji, tłum. P. Fast, Śląsk, Katowice 1997. 
Peter Verstraten, Film Narratology, Toronto University Press, Toronto 2009.

Michael Walker, Hitchcock's Motifs, Amsterdam University Press, Amsterdam 2005.

\section{Filmografia}

Trema [DVD], reż. Alfred Hitchcock, Galapagos 2016.

\section{(Self)reflexivity in Stage Fright by Alfred Hitchcock. On the Adaptation of Selwyn Jepson's Novel}

The article is devoted to self-reflexive strategies used in Stage Fright by Alfred Hitchcock, based on a novel Man Running by Selwyn Jepson. Unlike European modernists such as Jean-Luc Godard, Hitchcock didn't use experimental film form, but he applied some metafictional narrative techniques within a classical narrative structure. Comparing Stage Fright with the literary original, the author shows how Hitchcock made his film self-referential. The director achieved it by embedding the action deeper in a theater environment, adding a complex symbol of a curtain, using a figure of authorial metalepsis, problematizing the issue of the characters, identity and making narration unreliable. Stage Fright is self-reflexive not only on the level of the plot and dialogues, but also on the level of the narration. As the author argues, Hitchcock not only talks about the mechanisms of creating the spectacle, but also draws attention to the role of lies, fiction and play in our lives.

Keywords: Alfred Hitchcock, self-reflexivity, film adaptation, spectacle, modernist cinema, unreliable narration 